\title{
In vitro micropropagation of chive (Allium schoenoprasum L.)
}

\author{
MAREK LUBOMSKI \\ Laboratory of Tissue Cultures, Vitroflora International, Szosa Bydgoska 36, 86-065 Łochowo \\ near Bydgoszcz, Poland.
}

A bstact

\begin{abstract}
The investigations on micropropagation of Allium schoenoprasum embraced shoot formation from cultured shoot tips, shoot multiplication, root formations, and cold storage of rooted plants. All explants were cultured on modified Murashige-Skoog medium. Surface disinfection of shoots derived from stock plants was not necessary to obtain no infection culture. The highest shoot nultiplication was obtained on medium with $20 \mathrm{~g} \mathrm{I}^{-1}$ sucrose and $1.0 \mathrm{mg} \mathrm{I}^{-1}$ 6-benzylo. aminopurine (BA). Root formation was observed in both indoleacetic acid (IAA) and indolebutyric acid (IBA). Rooted plants were succesfully kept in cold storage $\left(5^{\circ} \mathrm{C} \pm 1^{\circ} \mathrm{C}\right.$ darkness). Only $20 \%$ of plants died after 6 months of storage.
\end{abstract}

\section{INTRODUCTION}

Studies on micropropagation of plants from the genus Allium are fairly numerous. Du st a n and S h ort (1977a, b, 1978, 1979 a), H u s s y (1978), F u j i e d a et al. (1979) and L a s s oc iń s ki et al. (1985) carried out studies on micropropagatiaon of A. cepa. D u s t a n and S h or t (1979b) worked out a method of $A$. parrum propagation, while $\mathrm{L}$ a s s o c i ń s $\mathrm{k}$ i et al. (1985) studied micropropagation of $A$. sativum and $\mathrm{S} \mathrm{h}$ a $\mathrm{h} i \mathrm{n}$ and $\mathrm{K}$ a $\mathrm{n}$ e $\mathrm{n} \mathrm{k}$ o (1986) of A. fistulosum. None of these works, however, gave any information on in vitro propagation of A. schoenoprasum.

The above authors studied shoot regeneration from callus tissue (D u s t a $\mathbf{n}_{*}$ and S hort 1977a, Sha hin and Ka ne n k 1986) and from various other plant parts as inflorescence or flower parts (D u s t a $\mathrm{n}$ and $\mathrm{S} \mathrm{h}$ or t, 1979b), 
shoot tips ( $\mathrm{F} \mathrm{u} \mathrm{j} \mathrm{i} \mathrm{e} \mathrm{d} \mathrm{a} \mathrm{et} \mathrm{al.} \mathrm{1977)} \mathrm{or} \mathrm{two} \mathrm{husk} \mathrm{onion} \mathrm{fragments} \mathrm{connected} \mathrm{with}$ a heel part ( $\mathrm{L}$ a s s o c i ń s k i et al. 1985). Cultures were either carried out on specially prepared media (D u s $\mathrm{t}$ a $\mathrm{n}$ and $\mathrm{S}$ h or t, 1977a-BDS medium) or media generally used for plant micropropagation (Hussey, 1978 - Murashige-Skoog medium, L a s s o c i ń s k i et al., 1985-Gamborg medium).

The results of these studies did not deal with the storage of in vitro Allium cultures in low temperatures. Cold storage in micropropagation could be used to create new clones or improved plant varietes, or else to rapidly propagate single cultured plants.

\section{MATERIAL AND METHODS}

In spring 1987 shoots were obtained from a commercial chive (Allium schoenoprasum L.) culture. These were sterilized for $20 \mathrm{~min}$. in $20 \%$ sodium hypochlorite and washed three times in sterile water, or only washed in sterile water without previous sterilization. Shoot tips 4 to $8 \mathrm{~mm}$ long were then isolated and implanted into a modified Murashige-Skoog (MS) medium. Modification consisted of the elimination of glycine and an increase of thiamine level to $0,5 \mathrm{mg} \mathrm{l}^{-1}$ ( $\mathrm{H} \mathrm{u} \mathrm{s} \mathrm{s} \mathrm{e} \mathrm{y,} \mathrm{1978).} \mathrm{As} \mathrm{regards} \mathrm{growth} \mathrm{regulators,} \mathrm{kinetin} \mathrm{(6-furfurylo-}$ aminopurine) $10 \mathrm{mg} \mathrm{l}^{-1}$ and NAA (naphthyl-1-acetic acid) $0,1 \mathrm{mg} \mathrm{l}^{-1}$ were used.

In order to propagate, the shoots were transplated to MS medium containing BA (6-benzyloaminopurine) $1,0 \mathrm{mg} \mathrm{l}^{-1}$ or kinetin $10 \mathrm{mg} \mathrm{l}^{-1}$ in a similar way as in the studies by L a s s o c i ń s k i et al. (1985). Studies were also made on the effect of sucrose levels upon shoot multiplication. To achieve this, 20 or $30 \mathrm{~g}$ of sucrose were added to 11 of the medium. In order to induce root formation, shoots were transplanted singly on MS medium containing $20 \mathrm{~g} \mathrm{l}^{-1}$ sucrose and IAA (indolyl-3-acetic acid) $1 \mathrm{mg} \mathrm{l}^{-1}$ or IBA (indolyl-3-butyric acid) $0,1 \mathrm{mg} \mathrm{l}^{-1}$ ( $\mathrm{S} \mathrm{h}$ a h in and $\mathrm{K}$ an enk o, 1986).

All experiments were conducted on solid media (Difco Bacto-Agar 0,8 \%), brought to $\mathrm{pH} 5,6$ before agar addition. The media were sterilized in an autoclave (20 min. at $1,1 \mathrm{~kg} \mathrm{~cm}^{-2}$ ). Growth of the cultures lasted for 4 weeks in $24^{\circ} \mathrm{C} \pm 2^{\circ} \mathrm{C}$, in glowing lamp light ( $3000 \mathrm{~lx})$, applying 16 hours of light and $8 \mathrm{~h}$ of darkness. 30) explants were used in each experiment. Number of tips regenerating shoots was recorded as well as number of shoots obtained from multiplication, and length and number of roots. All experiments were made in 2 replications, using 30 explants each time. Studies were also made on the possibility of storing rooted cultures in $5^{\circ} \mathrm{C} \pm 1^{\circ} \mathrm{C}$ in darkness. Plants were placed in a cold store room for 2,4 , or 6 months. Thereafter, plant growth in vitro in $24^{\circ} \mathrm{C} \pm 2^{\circ} \mathrm{C}$ was observed. 


\section{RESULTS}

After 4-week culture, $80 \%$ of the shoot tips used showed growth. They formed single shoots with 1 or 2 leaves (Fig. 1). The remaining $20 \%$ of the explants showed no shoot growth (17\%) or were infected $(3 \%)$. No differences were observed in the number of infected cultures between sterilized shoots and those washed in sterile water only.

Transplantation of the formed shoots on a medium containing BA or kinetin and NAA resulted in the formation of from 2,9 to 6,1 shoots (Tab. 1). Shoot multiplication was noticeably affected by sucrose levels in the medium. The highest shoot multiplication was observed at lower sucrose concentration $\left(20 \mathrm{mg} \mathrm{l}^{-1}\right)$ in both media. The highest number of shoots $(6,1)$ was obtained on the medium with $1 \mathrm{mg} \mathrm{l}^{-1} \mathrm{BA}$ and $20 \mathrm{mg} \mathrm{l}^{-1}$ sucrose (Fig. 2).

All shoots transplanted to the medium with IAA or IBA formed roots and new leaves. Use of $0,1 \mathrm{mg} \mathrm{l}^{-1}$ IBA gave better results than $1 \mathrm{mg} \mathrm{l}^{-1}$ IAA (Tab. 2). Shoots formed 6,8 roots $37 \mathrm{~mm}$ long on the average on the medium containing IBA.

Rooted chive shoots were tolerant to low temperature. Two-month cooling did not affect subsequent culture growth. Four-month cold storage of the cultures decreased slightly number of plants showing subsequent growth $(93 \%)$. Only prolongation of cold storage to 6 months noticeably decreased (to $80 \%$ ) number of plants with subsequent growth in $24^{\circ} \mathrm{C} \pm 2^{\circ} \mathrm{C}$.

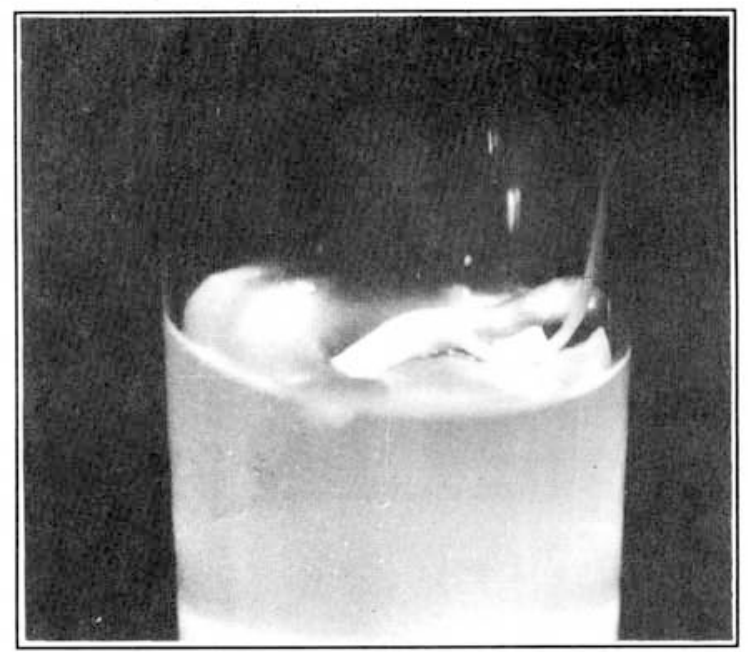

Fig. 1. Shoot formation from cultured shoot tips on the medium with kinetin $10 \mathrm{mg} \mathrm{l}^{-1}$ and NAA $0.1 \mathrm{mg} \mathrm{l}^{-1}$ 


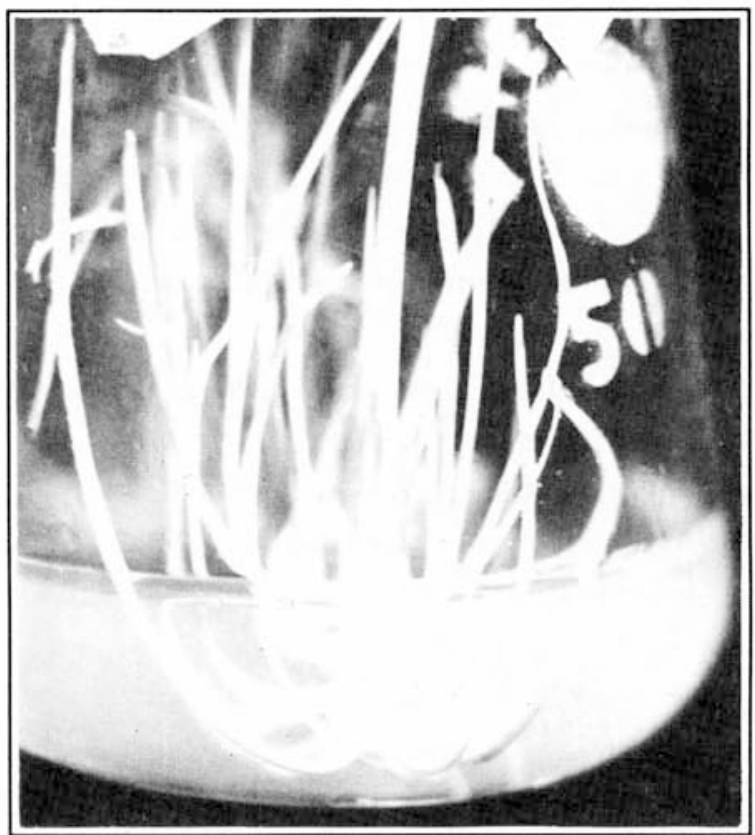

Fig. 2. Shoot multiplication on the medium with sucrose $20 \mathrm{~g} \mathrm{I}^{-1}$ and BA $1,0 \mathrm{mg} \mathrm{I}^{-1}$

Table 1

The effect of growth substances and sucrose on shoot multiplication of A. schoenoprasum L. ( 2 replications, 30 explants in each)

\begin{tabular}{|c|c|c|}
\hline $\begin{array}{c}\text { Growth regulators } \\
\left(\mathrm{mg} \mathrm{l}^{-1}\right)\end{array}$ & $\begin{array}{c}\text { Sucrose } \\
\left(\mathrm{g} \mathrm{l}^{-1}\right)\end{array}$ & $\begin{array}{c}\text { No. of shoots } \\
\text { per culture }\end{array}$ \\
\hline Kinetin 10, NAA 0,1 & 20 & 4,1 \\
& 30 & 3,1 \\
\hline BA 1,0 & 20 & 6,1 \\
& 30 & 2,9 \\
\hline
\end{tabular}

Table 2

The effect of growth substances on root formation from in vitro-derived shoots A. schoenoprasum L. ( 2 replications, 30 in each)

\begin{tabular}{|c|c|c|c|}
\hline $\begin{array}{c}\text { Growth regulators } \\
\left(\mathrm{mg} \mathrm{1}^{-1}\right)\end{array}$ & $\begin{array}{c}\text { No. of roots } \\
\text { per culture }\end{array}$ & $\begin{array}{c}\text { Average root } \\
\text { length }(\mathrm{mm})\end{array}$ & $\begin{array}{c}\text { Cultures with } \\
\text { roots }(\%)\end{array}$ \\
\hline IAA 1,0 & 5,9 & 34 & 100 \\
IBA 0,1 & 6,8 & 37 & 100 \\
\hline
\end{tabular}




\section{DISCUSSION}

Growth and development of in vitro Allium schoenoprasum cultures did not differ from other Allium species. Chive, similarly as onion ( $L$ a s s o c i ń s k i et al. 1985), need not to be sterilized before explant isolation.

Sucrose concentration noticeably affected shoot multiplication in contradistinction to A. cepa (H u s s e y, 1987) and A. fistulosum ( $\mathrm{S} \mathrm{h}$ a h i $\mathrm{n}$ and $\mathrm{K}$ a $\mathrm{n}$ e $\mathrm{n} \mathrm{k} \mathrm{o,} \mathrm{1986)} \mathrm{for} \mathrm{which} 30 \mathrm{~g} \mathrm{l}^{-1}$ of sucrose were used, chive shoots multiplied better at $20 \mathrm{~g} \mathrm{l}^{-1}$. Only Dustan and Short $(1978,1979 \mathrm{~b})$ recommended $20 \mathrm{~g} \mathrm{l}^{-1}$ sucrose for $A$. cepa and $A$. porrum cultures on a modified 85 medium.

D u s t a n and S h or t $(1978,1979$ b) used 2iP and NAA for shoot multiplication, while $\mathrm{S} \mathrm{h}$ a h i $\mathrm{n}$ and $\mathrm{K}$ a $\mathrm{n}$ e $\mathrm{n} \mathrm{ko} \mathrm{(1986)} \mathrm{applied} \mathrm{kinetin} \mathrm{and}$ 2,4 D. In case of chive, the medium containing BA $\left(1 \mathrm{mg} \mathrm{l}^{-1}\right)$ proved to be better than kinetin and NAA. Similar result was obtained by $\mathrm{D} u \mathrm{~s} t \mathrm{a} \mathrm{n}$ and $\mathrm{S} h$ or $\mathrm{t}$ (1979 a) in shoot regeneration from explants obtained from onion inflorescence. L a s s o c i ń s k i et al., (1985) obtained good growth of garlic on a medium with kinetin and NAA or with BA only. Root formation in chive was satisfactory on both media: with IAA and with IBA. D u s $t$ a $n$ and $S$ h or t (1979 a) recommended IAA for root formation in $A$. cepa cultures, but $\mathrm{S} \mathrm{h}$ a h i $\mathrm{n}$ and $\mathrm{K}$ a $\mathrm{n}$ e $\mathrm{n} \mathrm{k}$ o (1986) recommended IBA for A. fistulosum.

Studies showed that it was possible to store the plants in low temperatures during chive micropropagation. Studies on cold storage of in vitro cultures are rare. $\mathrm{P}$ a p a $\mathrm{c} \mathrm{h}$ a $\mathrm{t} \mathrm{z}$ i et al., (1981) stated that satisfactory results were achieved in storing Hosta decora cultures for 5 months. Chive can be stored for as long as 6 months.

\section{REFERENCES}

Du s 1 a n D. I., S h o r t K. C., 1977 a. Improved growth of tissue cultures of the onion, Allium cepa. Physiol. Plant. 41: 70-72.

D u s t a n D. I.. S h ort K. C., 1977 b. In vitro studies on organogenesis and growth in Allium cepa tissue cultures. Acta Hort. 78: 139-147.

D u $\leq t$ a n D. I., S h or t K. C., 1978. Shoot production from onion callus tissue cultures. Sci. Hort. 9: 99-110. Du st a n D. I., S h or t K. C., 1979a. Shoot production from the flower head of Allium cepa. Sci. Hort. 10: 345-356.

Du st a n D. I., S h o r t K. C., 1979b. Shoot production from cultured Allium porrum tissues. Sci. Hort. 11: $37-43$.

Fujie da K., An d o Y., Fu jit a Y., 1977. Propagation of welsh onion through shoot tip culture. J. Fac. Agr.. tissue culture. J. Japan Soc. Horn. Sci. 48: 186-194. 
H u s s e y G., 1978. In vitro propagation of the onion Allium cepa by axillary and adventitious shoot proliferation. Sci. Hort. 9: 227-236.

La s s oci ń sk i W., Góre ck a K., G 6 recki R., 1985. Preliminary report on onion (Allium cepa L.) and garlic (Allium sativum L.) propagation in vitro. Bull. Pol. Acad. Sci., Scn. Biol. 33: 23-26.

Pa pach a $\mathrm{z}$ i M., Ha m m e $\mathrm{P}$. A., H a s e g a w a P. M., 1981. In vitro propagation of Hosta decorata cv. Thomas Hogg using cultured shoot tips. J. Amer. Soc. Hort. Sci. 106-2: 232-236.

P i e r i k R. L. M., 1987. In vitro culture of higher plants. Martinus Nijhoff Publishers: 296-300.

$\mathrm{S}$ h a h i n E. A., K a n e n k o K., 1986.Somatic embryogenesis and plant regeneration from callus cultures of nonbulbing onions. Hort. Science 21-2: 294-295.

\section{Rozmnażanie szczypiorku (Allium schoenoprasum L.) metodą in vitro}

Streszczenie

Przeprowadzane badania nad mikrorozmnażaniem Allium schoenoprasum L. dotyczyły regeneracji pędów z wierzchotków pędów, mnożenia i ukorzeniania pędów oraz przetrzymywania ukorzenionych roślin w obniżonej temperaturze. Wszystkie doświadczenia przeprowadzono na zmodyfikowanej pożywce Murashige i Skooga. Wykazano, że pobrane pędy z roślin matecznych nie wymagają sterylizacji przed izolacją wierzchołków. Istołny wplyw na mnożenie pędów mialo stężenie sacharozy w pożywce. Najwyższe namnożenie pędów uzyskano na podłożu zawierającym $20 \mathrm{~g} \mathrm{l}^{-1}$ sacharozy i $1 \mathrm{mg} \mathrm{l}^{-1} \mathrm{BA}$. Pędy ukorzenialy się zarówno na podłożu z IAA jak i IBA. Ukorzenione rośliny wykazywały dużą odporność na przetrzymywanie w obniżonej temperaturze. Przez 6 miesięczny okres schładzania obumarło $20 \%$ roślin. 